\title{
Patterns of year-to-year variation in haemoglobin and glucose concentrations in the blood of nestling Pied Flycatchers Ficedula hypoleuca
}

\author{
Michał Glądalski $^{1} \cdot$ Joanna Skwarska $^{1} \cdot$ Adam Kaliński $^{3} \cdot$ Mirosława Bańbura $^{2}$ • \\ Marcin Markowski $^{1} \cdot$ Jarosław Wawrzyniak $^{1} \cdot$ Piotr Zieliński $^{4} \cdot$ Jerzy Bańbura $^{1}$
}

Received: 11 September 2014/Revised: 20 January 2015/Accepted: 5 March 2015/Published online: 17 March 2015

(c) The Author(s) 2015. This article is published with open access at Springerlink.com

\begin{abstract}
Physiological tools can be used to identify the sources and consequences of stressors on animals. Understanding the influences of variation in habitat quality and anthropogenic disturbance on organism condition and health may improve future management and conservation. We present results concerning variation in haemoglobin and glucose concentrations in the blood of about 14-day-old nestling Pied Flycatchers Ficedula hypoleuca in central Poland over a 4-year period, 2011-2014, in a deciduous forest. The most important findings of the study are: (1) the concentration of haemoglobin and glucose of the nestlings from the same brood tended to be consistently similar, with much variation occurring among broods; (2) repeatability of haemoglobin concentration was higher than repeatability of glucose concentration; (3) mean levels of haemoglobin and glucose varied among years; (4) haemoglobin and glucose concentrations were negatively correlated; and (5) there was a positive relationship between haemoglobin levels and breeding success.
\end{abstract}

Communicated by K. C. Klasing.

Michał Glądalski

mglad@biol.uni.lodz.pl

1 Department of Experimental Zoology and Evolutionary Biology, Faculty of Biology and Environmental Protection, University of Łódź, Banacha 12/16, 90-237 Lodz, Poland

2 Museum of Natural History, Faculty of Biology and Environmental Protection, University of Łódź, Kilińskiego 101, 90-011 Lodz, Poland

3 Department of Teacher Training and Biological Diversity Studies, Faculty of Biology and Environmental Protection, University of Łódź, Banacha 1/3, 90-237 Lodz, Poland

4 Department of Ecology and Vertebrate Zoology, Faculty of Biology and Environmental Protection, University of Łódź, Banacha 12/16, 90-237 Lodz, Poland
Keywords Passerine $\cdot$ Body condition $\cdot$ Physiological condition $\cdot$ Hematology $\cdot$ Breeding success

\section{Zusammenfassung}

Muster der jährlichen Schwankungen in der Hämoglobin- und Glukose-Konzentration bei Nestlingen des Trauerschnäppers Ficedula hypoleuca

Physiologische Werkzeuge können genutzt werden, um Quellen und Auswirkungen von Stressoren auf Tiere zu identifizieren. Einflüsse von Schwankungen in Habitatqualität und anthropogene Störungen auf Lebensbedingungen und Gesundheit von Organismen zu verstehen, könnte zukünftig Management und Schutz verbessern. Wir stellen Ergebnisse einer vierjährigen Untersuchung (2011-2014) von Schwankungen in Hämoglobin-und Glukose-Konzentration im Blut von etwa 14 Tage alten Nestlingen des Trauerschnäppers (Ficedula hypoleuca) in einem Laubwald in Zentral-Polen vor. Die wichtigsten Befunde sind: (a) die Hämoglobin- und Glukose-Konzentration der Nestlinge derselben Brut waren nahezu immer ähnlich, mit hohen Unterschieden zwischen verschiedenen Bruten, (b) die Übereinstimmung der HämoglobinKonzentration bei Wiederholungsmessungen war höher als die der Glukose-Konzentration, (c) die mittle Hämoglobinund Glukose-Konzentration unterschied sich von Jahr zu Jahr, (d) Hämoglobin- und Glukose-Konzentration waren negativ korreliert, (e) es gab einen positiven Zusammenhang zwischen Hämoglobin-Konzentration und Bruterfolg.

\section{Introduction}

Physiological knowledge can improve predictions of organism responses to environmental change, and also provide tools to support evidence-based management 
decisions (Cook et al. 2013); Prosser (1991) argued that there is a need for more physiological information on stress affecting individual species. Understanding the influences of variation in habitat quality and anthropogenic disturbance on organism condition and health could improve conservation (Cooke and O'Connor 2010; Ellis et al. 2012).

In altricial birds, during the critically demanding nesting stage, various components of reproductive effort accumulate and corresponding trade-offs become visible (Calow 1979). Thus, some parents cannot invest enough resources to raise offspring of high physiological quality (Sibly and Calow 1986). Nestlings that are in better condition have the chance to more effectively deal with various hazards, such as periods of food shortage, disease or parasitic infestation (Ots et al. 1998; Bańbura et al. 2004). Studies have shown that some blood parameters provide useful indicators of the body condition and state of health of animals, including birds (Atwal et al. 1964; Bradley and Threlfall 1974), when collected and interpreted with appropriate caution (Fair et al. 2007; Lill 2011; Lill et al. 2013). Blood components are good indicators for evaluating short-term stress in the environment (Brown 1996; Sergent et al. 2004). A high diagnostic value of the basic blood parameters results from the close connection of these parameters to factors such as age, physiological condition, circadian rhythms, nutritional status, and others (Yadava 1978; Gee et al. 1981; GarcíaRodríguez et al. 1987; Cerolini et al. 1990; Abelenda et al. 1993; Kostelecka-Myrcha 1997; Sergent et al. 2004).

Haemoglobin is a simple biochemical indicator of bird metabolism (Sergent et al. 2004; Nadolski et al. 2006; Simmons and Lill 2006) that reflects the nutritional status of the animal, its hydration, and the presence of parasites and pathogens, and allows for the estimation of mineral deficiency (Campbell and Dein 1984; Campbell 1995). Stressors also contribute to changes in the level of haemoglobin, e.g., increasing the ambient temperature causes changes in the concentration of haemoglobin (Wilson 1971), and nutritional deficiencies cause a noticeable drop in the level of haemoglobin (Kasprzyk et al. 2006). Studies showed also that changes in haemoglobin could be caused by natural factors that include age, sex, energy expenditure, parasite pressure and genetics (Clark and Mason 1988; Dufva and Allander 1996; Simon et al. 2004; Słomczyński et al. 2006; Fair et al. 2007).

Glucose is also considered to be an indicator of the nutritional condition of birds (Fairbrother et al. 1990; Remage-Healey and Romero 2001; Casado et al. 2002; Dunbar et al. 2005; Kaliński et al. 2014). The level of this monosaccharide in passerine birds usually ranges from 200 to $500 \mathrm{mg} / \mathrm{dL}$ (Lewandowski et al. 1986; Harris 1991), and is more than $800 \mathrm{mg} / \mathrm{dL}$ in hummingbirds (Diamond et al. 1986). Stress factors also raise the level of energy expenditure by the animal and reduce its availability for other physiological processes. As a result of severe environmental stress, the blood glucose level rises (Graczyk et al. 2003).

Our previous findings on tits showed that the level of concentration of haemoglobin corresponds positively with body condition (on the Great Tit Parus major: Nadolski et al. 2006, on the Blue Tit Cyanistes caeruleus: Bańbura et al. 2007), while glucose is an inverse index of condition (on the Blue Tit: Kaliński et al. 2014). Therefore, a negative correlation between the concentration of haemoglobin and glucose would be expected, as recently reported by Minias (2014).

In this paper, we analyse year-to-year variation in haemoglobin and blood glucose concentrations of nestling Pied Flycatcher Ficedula hypoleuca. Our analysis of the data is aimed at (1) investigating whether haemoglobin and blood glucose concentrations are consistent physiological characteristics of Pied Flycatcher broods, with low variation within broods and high variation among broods; (2) presenting year-to-year variation in levels of both of these condition indicators; (3) analysing the relation of haemoglobin level to glucose level; (4) examining the impact of weather parameters on both of these condition indicators; and (5) showing whether Pied Flycatcher breeding success is linked to both of these physiological condition indicators and to mass of nestlings. It is worth mentioning that we are not aware of any published results analysing differences in haemoglobin and glucose concentrations between years, or their relation to each other in Pied Flycatcher nestlings.

\section{Materials and methods}

This study, carried out during four breeding seasons from 2011 to 2014, is part of a long-term project of research into the breeding biology of secondary cavity nesters around Łódź, central Poland. The forest study area $\left(51^{\circ} 50^{\prime} \mathrm{N}\right.$, $19^{\circ} 29^{\prime} \mathrm{E}$ ), bordering on the NE part of the city, is a c. 130 ha area in the center of mature mixed deciduous forest (1250 ha in total) with oaks Quercus robur and Q. petraea as predominating tree species.

The study site was supplied with 300 standard wooden nestboxes (Lambrechts et al. 2010). For every breeding season, the nestboxes were first occupied by Blue Tits and Great Tits. Pied Flycatchers arrived at the breeding area later, and occupied free nestboxes (Skwarska et al. 2012). During the breeding season, the nestboxes were visited at least once a week (or every day if needed) to record laying date, clutch size, the number of nestlings and the nestlings' basic developmental traits. The Pied Flycatcher nestlings were banded with individually numbered metal rings and measured (wing length, to the nearest $1 \mathrm{~mm}$ and body 
mass, to the nearest $0.1 \mathrm{~g}$ ) 13-14 days after the hatching of the first egg (nestlings fledge on c. the18th day in our study population). A random subsample of three nestlings, blinddrawn out of same-age nestlings from every Pied Flycatcher brood, was designated for blood sampling. Samples of c. $5 \mu \mathrm{L}$ of blood were taken from the ulnar vein of nestlings, placed in HemoCue cuvettes, and analysed in the field using a portable HemoCue $\mathrm{Hb} 201+$ photometer to measure haemoglobin concentration $(\mathrm{g} / \mathrm{L})$. A portable HemoCue Glucose 201+ photometer (HemoCue AB, Angelholm, Sweden) was used to establish blood glucose concentration $(\mathrm{mg} / \mathrm{dL})$ in another sample of blood. All field procedures were carried out between 9.00 AM and 2.00 PM. During the 4 years of the study, 111 nestlings (2011-27, 2012-36, 2013-30, 2014-18) from 37 broods of Pied Flycatcher were examined.

Yearly means of haemoglobin levels and glucose levels were tested for correlation with the following average weather variables for the same years: mean daily minimum temperature and mean rainfall. The above correlations with weather variables were analysed for a 14-day period, beginning on the first hatching day in a given year for a given nest. The weather data for Łódź were obtained from TuTiempo.net climate data base (http://www.tutiempo.net/ en/Climate/LODZ/124650.htm). The repeatability of haemoglobin and blood glucose concentrations within broods was calculated as intraclass correlation to test to what extent nestlings in broods tend to resemble one another (Zar 1996). A high repeatability indicates that variation within individual broods is much smaller than among different broods (Bańbura and Zieliński 1990). Repeatability is low if measurements within broods are very different. Because haemoglobin and glucose concentrations in the blood of nestlings from the same brood were not independent, the individual nestling values were treated as unit records and analysed using mixed linear models, with brood ID being included as a random factor controlling for clustering; restricted maximum likelihood estimates were used and degrees of freedom were approximated by the Satterthwaite method (Heck et al. 2010). Effects of year on the haemoglobin and glucose concentrations were modelled in an ANCOVA style by fitting a model that included wing length as an age-controlling covariate (Crawley 2002). Relationships between haemoglobin concentration, blood glucose level, nestling mass and breeding success (breeding success refers to the proportion of eggs resulting in young that left the nest) were examined using a generalized linear model with binomial error distribution, logit link function, and Wald Chi squared test statistics (Crawley 2002). Relations between yearly mean haemoglobin concentration, yearly mean blood glucose level and weather variables were examined using Pearson's linear correlation. Pearson correlations were calculated in STATISTICA 10
(StatSoft Inc. 2011). Mixed linear models and generalized linear models were calculated using IBM SPSS 15.0 software (Heck et al. 2010; SPSS 2006).

\section{Results}

The concentration of haemoglobin of the nestlings from the same brood tended to be consistently similar, with much variation occurring among broods, resulting in significant within-brood repeatability $(R=0.63 \pm 0.08 \quad(\mathrm{SE})$, $\left.F_{38 ; 72}=6.19, p<0.001\right)$. The concentration of the blood glucose of the nestlings from the same brood also tended to be consistently similar, with much variation occurring among broods, resulting in significant within-brood repeatability $\quad\left(R=0.32 \pm 0.11 \quad(\mathrm{SE}), \quad F_{38 ; 70}=2.39\right.$, $p<0.001)$.

Haemoglobin concentration and blood glucose concentration in nestling Pied Flycatchers differed between years (Table 1). The minimum individual haemoglobin level was $101 \mathrm{~g} / \mathrm{L}$ (2012), and the maximum individual value was $167 \mathrm{~g} / \mathrm{L}$ (2014). Corresponding brood mean values were $103.67 \mathrm{~g} / \mathrm{L}$ (2012) and $157 \mathrm{~g} / \mathrm{L}$ (2014, Fig. 1). The minimum individual glucose concentration was $161 \mathrm{mg} / \mathrm{dL}$ (2014), and the maximum individual value was $394 \mathrm{mg} / \mathrm{dL}$ (2012). Corresponding brood mean values were $175.67 \mathrm{mg} / \mathrm{dL}$ (2014) and $341 \mathrm{mg} / \mathrm{dL}$ (2012, Fig. 1). The mean haemoglobin level and the mean blood glucose level were negatively correlated $(R=-0.34, \quad N=37$, $P=0.04)$.

For the 14-day-long period beginning on the first hatching day, mean daily minimum temperatures significantly affected mean haemoglobin levels $(R=0.34$, $N=37, p=0.04$, Fig. 2). There was a marginally nonsignificant positive correlation between the mean haemoglobin levels and mean rainfall $(R=0.31, N=37$, $p=0.06)$. There was also a marginally nonsignificant negative correlation between the mean blood glucose levels and mean rainfall $(R=-0.30, N=37, p=0.07)$.

Table 1 Linear mixed model tests for the effects of year on haemoglobin and glucose concentrations in the blood of nestling Pied Flycatchers

\begin{tabular}{llll}
\hline$Y$-variable and effects & $d f$ & $F$ & $p$ \\
\hline Haemoglobin & & & \\
$\quad$ Year & $3 ; 33.96$ & 6.30 & $\mathbf{0 . 0 0 2}$ \\
$\quad$ Wing length (cov) & $1 ; 57.14$ & 12.09 & $\mathbf{0 . 0 0 1}$ \\
Glucose & & & \\
$\quad$ Year & $3 ; 31.74$ & 6.30 & $\mathbf{0 . 0 0 2}$ \\
Wing length (cov) & $1 ; 37.30$ & 8.56 & $\mathbf{0 . 0 0 6}$ \\
\hline
\end{tabular}

$\overline{\text { Wing length was used as a covariate (significant } p \text { values in the model }}$ are in bold) 

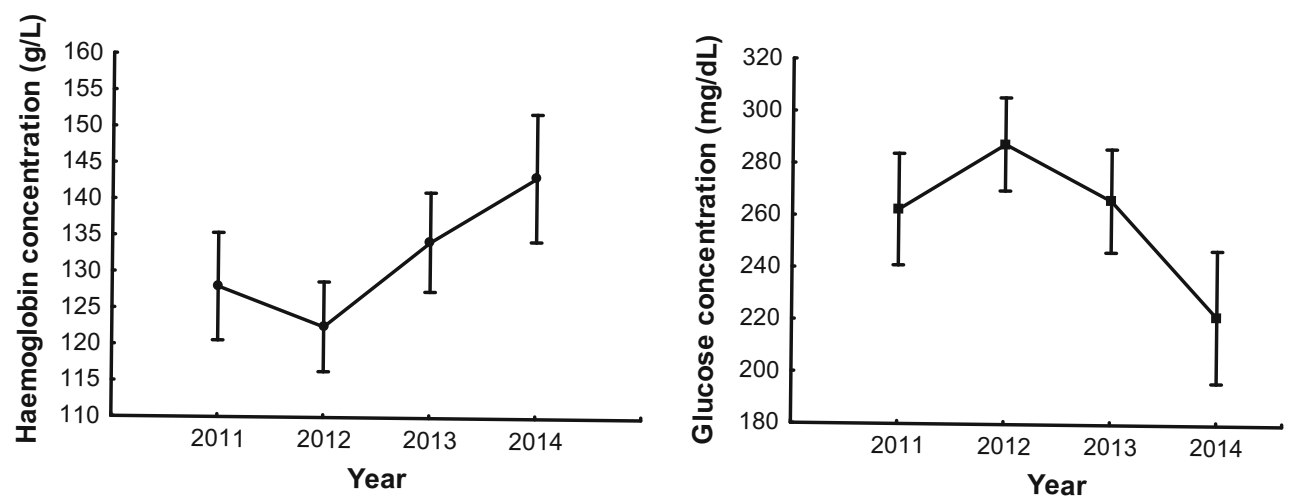

Fig. 1 Annual variation in mean haemoglobin and mean blood glucose concentrations in the blood of Pied Flycatcher nestlings. Mean \pm standard errors corrected for wing length as covariate are shown

There was a positive relationship between breeding success of Pied Flycatchers and the per-brood mean haemoglobin concentration in nestling blood and mean nestling mass (Table 2). There was no significant relation between breeding success and mean blood glucose level (Table 2). The same relationships were revealed when mean haemoglobin and mean glucose were analysed in separate models (generalized linear models: Wald $\chi_{1}^{2}=4.00, p=0.046$ for haemoglobin model; Wald $\chi_{1}^{2}=0.54, p=0.46$ for glucose model).

\section{Discussion}

We are not aware of any published results showing differences in haemoglobin and glucose concentrations between years, or the relationship between haemoglobin and glucose levels in Pied Flycatcher nestlings. The differences in haemoglobin and glucose levels between individual nestlings within a brood being low in relation to differences among separate broods have been described in tit species (repeatability of haemoglobin for Great Tits: 0.53, Nadolski et al. 2006, for Blue Tits: 0.53-0.77, Bańbura et al. 2007 and repeatability of glucose: 0.43 , Kaliński et al. 2014). Repeatability of glucose (0.32) in our study is lower than that for haemoglobin (0.63), which is in agreement with our previous findings on tits, but more studies are needed to determine whether it may be considered as a general pattern in wild populations of birds. A value of glucose repeatability that is lower than that for haemoglobin repeatability suggests that blood glucose fluctuates more. Glucose concentrations (in contrast to haemoglobin) probably show rapid changes in response to food intake, so that if all the chicks are not fed by the parents simultaneously, then glucose concentrations are expected to show more intrabrood variation. It could also be that haemoglobin concentration responds more to the factors acting on entire broods during the whole nestling stage, such as general trophic conditions and parasitic pressure in the nest, which would further explain higher intrabrood repeatability of this measure. Potti et al. (1999) assessed within-brood repeatability of haematocrit in Pied Flycatcher nestlings and found it to be 0.7 , which is similar to our result for haemoglobin.

Haemoglobin and glucose concentrations were negatively correlated. Our previous findings on tits foresaw the possibility of such a relationship (Bańbura et al. 2007; Kaliński et al. 2014), and it would be expected, assuming that hyperglycaemic states are likely to co-occur with anaemic symptoms in vertebrates. Minias (2014) found a strong negative correlation between the concentrations of haemoglobin and glucose in adult Whiskered Tern Chlidonias hybrida. This author stated that he was not aware of any other studies with empirically evaluated associations between blood concentrations of haemoglobin and glucose in wild populations of birds, and that more empirical studies were necessary to determine whether it could be considered as a general pattern in wild-living avian species. Our data confirm the existence of this pattern, being presumably the second study that shows this relationship, and the first to show it in Pied Flycatcher.

It is likely that one of the factors responsible for variation in the level of haemoglobin between years was the weather. Our results suggest that in springs with lower temperatures, mean haemoglobin levels are lower and there was a tendency (marginally nonsignificant positive correlation) suggesting that moderate rainfall may have some positive impact on haemoglobin concentration and a negative impact on glucose concentration. A low temperature inhibits activity of insects (Mellanby 1939; Bale 2002), and very low temperatures may partly reduce prey accessibility for birds (Kaliński et al. 2014). Low temperatures may also reduce female capacity for warming chicks efficiently (Kaliński et al. 2014). Thus a 


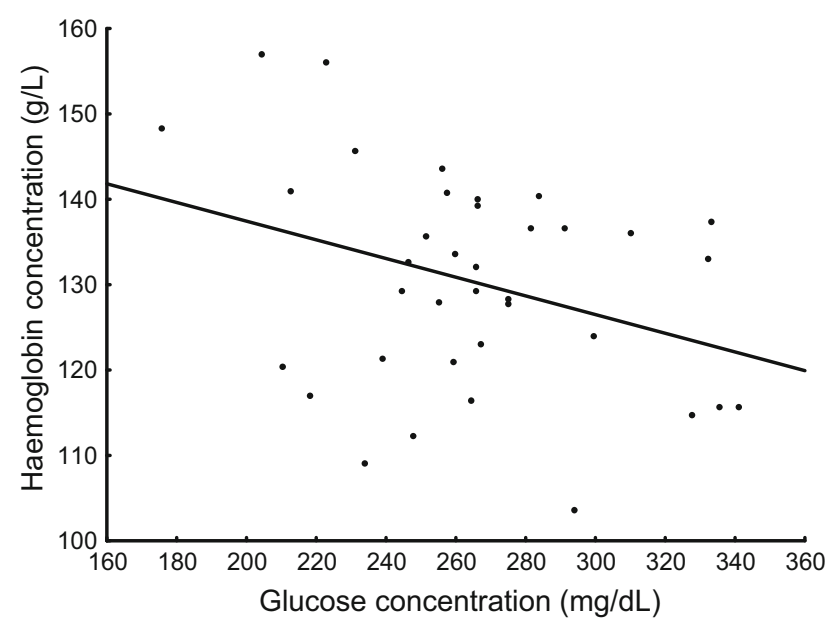

Fig. 2 Relationship between concentrations of haemoglobin and glucose in nestling Pied Flycatchers. The line represents the fitted regression

Table 2 Results of generalized linear binomial models showing correlative relationship of mean haemoglobin concentration, mean glucose concentration and mean nestling mass on breeding success (the number of fledglings in relation to clutch size) of Pied Flycatcher broods

\begin{tabular}{lrlll}
\hline Effects & \multicolumn{1}{l}{ Est \pm SE } & Wald $\chi^{2}$ & $d f$ & $\mathrm{p}$ \\
\hline Mean haemoglobin & $0.038 \pm 0.019$ & 4.00 & 1 & $\mathbf{0 . 0 4 6}$ \\
Mean glucose & $-0.004 \pm 0.006$ & 0.54 & 1 & 0.463 \\
Mean mass & $0.467 \pm 0.238$ & 3.86 & 1 & $\mathbf{0 . 0 4 9}$ \\
\hline
\end{tabular}

Significant $p$ values in the model are in bold

combination of mild temperatures and regular but not heavy rainfall provides good conditions and stimulates the development of rich arthropod communities (Southwood 1984; Bolger et al. 2005; Kaliński et al. 2009). Extreme rainfall would probably cause the reverse situation, due to hindered foraging (Zając 1995; Radford et al. 2001).

Haemoglobin concentration and body mass have turned out to be predictors of breeding success. Broods that were characterized by levels of haemoglobin and higher mass had higher breeding success. This result is in tune with our previous findings on tit species (Nadolski et al. 2006; Kaliński et al. 2009). In many bird species, the condition of nestlings is often linked to the probability of survival to the fledging stage, and later for final individual success in recruiting to the breeding population (Brown 1996). Haemoglobin concentration is functionally related to oxygen carrying capacity, which is sensitive to the nutritional state, as well as hydration and mineral deficiencies (Amand 1986; Campbell 1995). Body weight, frequently used as a reliable and easy-to-obtain condition index (SchulteHostedde et al. 2005; Labocha and Hayes 2012), depends on many environmental and individual factors (van Noordwijk et al. 1988; Acquarone et al. 2002; Cucco et al. 2002). One of the important environmental factors affecting condition indicators is the amount and quality of food, as well as diversity of nutrients, affecting daily pattern and body mass index (Owen et al. 2005; Labocha and Hayes 2012). Naef-Daenzer and Keller (1999) showed for tits that the pattern of variation in the abundance of caterpillars (main food during the breeding season for tits) reflects average body condition of nestlings. Bańbura et al. (2007) showed for Blue Tits that haemoglobin concentration correlates directly with food-abundance pattern differences between years. Thus, it would seems reasonable that foodabundance is partly responsible for variations in haemoglobin levels in Pied Flycatcher nestlings.

Kaliński et al. (2014) showed in tits that high glucose levels negatively affected fledging and breeding success. We found no such a pattern in Pied Flycatcher nestlings. Kern et al. (2001) analyzed glucose concentrations in Pied Flycatcher nestlings. Blood glucose was little affected by fasting, but increased throughout development. Their results showing that glucose concentration was not a very good indicator of nutritional status is consistent with our findings from a Polish population. Blood glucose also tends to show rapid changes within a very short period of time, and may show circadian rhythms and seasonal variation, and also depends on other factors (Bairlein 1983; Totzke and Bairlein 1998; Remage-Healey and Romero 2000; Prinzinger and Misovic 2010; Scanes and Braun 2013). Additionally, perhaps this relationship was more subtle than haemoglobin-breeding success, and a relatively small sample size and only four breeding seasons made it impossible to detect.

Our data support the idea that haemoglobin concentration may be considered a reliable condition indicator and is useful in field studies of the ecophysiology of Pied Flycatchers. While glucose concentration is probably also indicative of condition, it is usually much more difficult to interpret, and it may fluctuate more due to uncontrollable factors. More studies are needed to examine whether negative haemoglobin-glucose relations and differences between haemoglobin and glucose repeatabilities may be considered to be general patterns in wild populations of birds.

Acknowledgments All procedures were approved by the Local Ethical Committee and the State Office for Environment Protection. We thank A. Jaksa, D. Mańkowska, M. Janiszewska and J. Białek for their help and consent in conducting research in the areas under their administration. The study was founded by a grant from the Polish Ministry of Science and Higher Education No. N N304 045136 and University of Łódź (No. 506/829). We are obliged to P. Procter for linguistic consultation. We thank both reviewers for their valuable and constructive comments. 
Open Access This article is distributed under the terms of the Creative Commons Attribution License which permits any use, distribution, and reproduction in any medium, provided the original author(s) and the source are credited.

\section{References}

Abelenda M, Nava PM, Fernandez A, Alonso JA, Alonso JC, MunozPulido R, Bautista LM, Puerta ML (1993) Blood values of common cranes (Grus grus) by age an season. Comp Biochem Physiol A 104:575-578

Acquarone C, Cucco M, Cauli SL, Malacarne G (2002) Effects of food abundance and predictability on body condition and health parameters: experimental tests with the hooded crow. Ibis 144:155-163

Amand WB (1986) Avian clinical hematology and blood chemistry. W. B. Saunders Company, Philadelphia

Atwal OS, McFarland LA, Wilson WO (1964) Hematology of Coturnix from birth to maturity. Poult Sci 43:1392-1401

Bairlein F (1983) Seasonal variations of serum glucose levels in a migratory songbird, Sylvia borin. Comp Biochem Physiol A 76:397-399

Bale JS (2002) Insects and low temperatures: from molecular biology to distributions and abundance. Phil Trans R Soc Lond B 357:849-862

Bańbura J, Zieliński P (1990) Within-clutch repeatability of egg dimensions in the black-headed gull Larus ridibundus. J Ornithol 131:305-310

Bańbura J, Perret P, Blondel J, Thomas DW, Cartan-Son M, Lambrechts MM (2004) Effects of Protocalliphora parasites on nestling food composition in Corsican blue tits Parus caeruleus: consequences for nestling performance. Acta Ornithol 39:93-103

Bańbura J, Bańbura M, Kaliński A, Skwarska J, Słomczyński R, Wawrzyniak J, Zieliński P (2007) Habitat and year-to-year variation in haemoglobin concentration in nestling Blue Tits Cyanistes caeruleus. Comp Biochem Physiol A 148:572-577

Bolger DT, Patten MA, Bostock DC (2005) Avian reproductive failure in response to an extreme climatic event. Oecologia 142:398-406

Bradley LW, Threlfall W (1974) Blood cell indices of five species of auk (Alcidae) from Newfoundland, Canada. J Zool 174:377-385

Brown ME (1996) Assessing body condition in birds. Curr Ornithol 13:67-135

Calow P (1979) The cost of reproduction-a physiological approach. Biol Rev 54:23-40

Campbell TW (1995) Avian hematology and cytology, 2nd edn. Iowa University Press, Ames

Campbell TW, Dein FJ (1984) Avian hematology, the basics. Veterinary clinics of North America-small animal. Practice 14:223-248

Casado E, Balbontin J, Ferrer M (2002) Plasma chemistry in booted eagle (Hieraetus pennatus) during breeding season. Comp Biochem Physiol A 131:233-241

Cerolini S, Baldi A, Cavalchini LG (1990) Blood and plasma biochemical variables an laying hens of different strains and ages. Arch Geflugelk 54:190-194

Clark L, Mason JR (1988) Effects of biologically active plants used as nest material and the derived benefit to starling nestlings. Oecologia 77:174-180

Cook CN, Mascia MB, Schwartz MW, Possingham HP, Fuller RA (2013) Achieving conservation science that bridges the knowledge-action boundary. Conserv Biol 27:669-678

Cooke SJ, O'Connor CM (2010) Making conservation physiology relevant to policy makers and conservation practitioners. Conserv Lett 3:159-166
Crawley MJ (2002) Statistical computing: an introduction to data analysis using S-Plus. Wiley, Chichester

Cucco M, Ottonelli R, Raviola M, Malacarne G (2002) Variations of body mass and immune function in response to food unpredictability in magpies. Acta Oecol 23:271-276

Diamond JM, Karasov WH, Phan D, Carpenter FL (1986) Digestive physiology is a determinant of foraging bout frequency in hummingbirds. Nature 320:62-63

Dufva R, Allander K (1996) Variable effects of the Hen Flea Ceratophyllus gallinae on the breeding success of the Great Tit Parus major in relation to weather conditions. Ibis 138:772-777

Dunbar MR, Gregg MA, Crawford JA, Giordano MG, Tornquist ST (2005) Normal hematological and biochemical values for prelaying greater sage grouse (Centrocercus urophasianus) and their influence on chick survival. J Zoo Wildl Med 36:422-429

Ellis R, McWhorter TJ, Maron M (2012) Integrating landscape ecology and conservation physiology. Landsc Ecol 27:1-12

Fair J, Whitaker S, Pearson B (2007) Sources of variation in haematocrit in birds. Ibis 149:535-552

Fairbrother A, Craig MA, Walker K, O'Loughlin D (1990) Changes in mallard (Anas platyrhynchos) serum chemistry due to age, sex, and reproductive condition. J Wild Dis 26:67-77

García-Rodríguez T, Ferrer M, Carrillo JC, Castroviejo J (1987) Circadian rhythms of determined blood chemistry values in buzzards and eagle owls. Comp Biochem Physiol A 88:663-669

Gee GF, Carpenter W, Heusler GL (1981) Species differences in hematological values of captives cranes, raptors and quail. J Wildl Manage 45:463-483

Graczyk S, Piaszczak-Król A, Kotoński B, Wilczek J, Chmielak Z (2003) Examination of hematological and metabolic changes mechanisms of acute stress in Turkeys. Electron J Pol Agric Univ 6:5

Harris DJ (1991) Laboratory testing in pet avian medicine. 1147-1156. In: Rosskopf WJ, Woerpel RW (eds) The veterinary clinics of North America. 21. W. B.Saunders, Philadelphia

Heck RH, Thomas SL, Tabata LN (2010) Multilevel and longitudinal modeling with IBM SPSS. Routledge, New York

Kaliński A, Wawrzyniak J, Bańbura M, Skwarska J, Zieliński P, Bańbura J (2009) Haemoglobin concentration and body conditions of nestling Great Tits Parus major: a comparison of first and second broods in two contrasting seasons. Ibis 151:667-676

Kaliński A, Bańbura M, Glądalski M, Markowski M, Skwarska J, Wawrzyniak J, Zieliński P, Cyżewska I, Bańbura J (2014) Landscape patterns of variation in blood glucose concentration of nestling blue tits (Cyanistes caeruleus). Landsc Ecol 29:1521-1530

Kasprzyk M, Hetmański T, Kulczykowska E (2006) Changes In hematological parameters In free-living pigeons (Columbia livia f. urbana) during the breeding cycle. J Ornithol 147:599-604

Kern M, Bacon W, Long D, Cowie RJ (2001) Possible roles for corticosterone and critical size in the fledging of nestling pied flycatchers. Physiol Biochem Zool 74:651-659

Kostelecka-Myrcha A (1997) The ratio of amount of haemoglobin to total surface area of erythrocytes in birds in relation to body mass, age of nestling, and season of the year. Physiol Zool 70:278-282

Labocha MK, Hayes JP (2012) Morphometric indices of body condition in birds: a review. J Ornithol 153:1-22

Lambrechts M, Adriaensen F, Ardia DR, Artemyev AV, Atiénzar F, Bańbura J, Barba E, Bouvier J-C, Camprodon J, Cooper CB, Dawson RD, Eens M, Eeva T, Faivre B, Garamszegi LZ, Goodenough A, Gosler A, Grégoire A, Griffith SC, Gustafsson L, Johnson LS, Kania W, Keišs O, Llambias PE, Mainwaring MC, Mänd R, Massa B, Mazgajski TD, Møller AP, Moreno J, Naef-Daenzer B, Nilsson J-A, Norte AC, Orell M, Otter KA, Park CR, Perrins CM, Pinowski J, Porkert J, Potti J, Remes V, 
Richner H, Rytkönen S, Shiao M-T, Slagsvold Silverin B, Smith HG T, Sorace A, Stenning MJ, Stewart I, Thompson CF, Tryjanowski P, van Török J, Noordwijk AJ, Winkler and Ziane DW (2010) The design of artificial nestboxes for the study of secondary hole-nesting birds: a review of methodological inconsistencies and potential biases. Acta Ornithol 45:1-26

Lewandowski AH, Campbell TW, Harrison GJ (1986) Clinical chemistry: 192-200. In: Harrison GJ, Harrison LR (eds) Clinical avian medicine and surgery. Saunders, Philadelphia

Lill A (2011) Sources of variation in blood glucose concentrations of free-living birds. Avian Biol Res 4:78-86

Lill A, Rajchl K, Yachou-Wos L, Johnstone CP (2013) Are haematocrit and haemoglobin concentration reliable body condition indicators in nestlings: the welcome swallow as a case study. Avian Biol Res 6:57-66

Mellanby K (1939) Low temperature and insect activity. Proc Roy Soc Lond B 849:473-487

Minias P (2014) High glucose concentrations are associated with symptoms of mild anaemia in Whiskered Terns: consequences for assessing physiological quality in birds. J Ornithol 155:1067-1070

Nadolski J, Skwarska J, Kaliński A, Bańbura M, Śniguła R et al (2006) Blood parameters as consistent predictors of nestling performance in great tits (Parus major) in the wild. Comp Biochem Physiol A 143:50-54

Naef-Daenzer B, Keller LF (1999) The foraging performance of great and blue tits (Parus major and P. caeruleus) in relation to caterpillar development, and its consequences for nestling growth and fledging weight. J Anim Ecol 68:708-718

Ots I, Murumagi A, Horak P (1998) Haematological health state indices of reproducing great tits: methodology and sources of natural variation. Funct Ecol 12:700-707

Owen JC, Sogge MK, Kern MD (2005) Habitat and sex differences in physiological condition of breeding Southwestern willow flycatchers (Epidonax traillii extimus). Auk 122:1261-1270

Potti J, Moreno J, Merino S, Frias O, Rodriguez R (1999) Environmental and genetic variation in the haematocrit of fledgling pied flycatchers Ficedula hypoleuca. Oecologia 120:1-8

Prinzinger R, Misovic A (2010) Age-correlation of blood values in the Rock Pigeon (Columba livia). Comp Biochem Physiol A 156:351-356

Prosser CL (1991) Comparative animal physiology, vol 4. WileyLiss, New York

Radford AN, McCleery RH, Woodburn RJW, Morecroft MD (2001) Activity patterns of parent Great Tits Parus major feeding their young during rainfall. Bird Study 48:217-220

Remage-Healey L, Romero LM (2000) Daily and seasonal variation in response to stress in captive starlings (Sturnus vulgaris): glucose. Gen Comp Endocrinol 119:60-68

Remage-Healey L, Romero ML (2001) Corticosterone and insulin interact to regulate glucose and triglyceride levels during stress in a bird. Am J Physiol Regul Integr Comp Physiol 281:R994R1003

Scanes CG, Braun E (2013) Avian metabolism: its control and evolution. Front Biol 8:134-159

Schulte-Hostedde AI, Zinner B, Millar JS, Hickling GJ (2005) Restitution of mass-size residuals: validating body condition indices. Ecology 86:155-163

Sergent N, Rogers T, Cunningham M (2004) Influence of biological and ecological factors on hematological values in wild Little Penguins, Eudyptula minor. Comp Biochem Physiol A 138:333-339

Sibly RM, Calow P (1986) Physiological ecology of animals. Blackwell, Oxford

Simmons A, Lill A (2006) Development of parameters influencing blood oxygen carrying capacity in the welcome swallow and fairy martin. Comp Biochem Physiol A 138:333-339

Simon A, Thomas DW, Blondel J, Per P, Lambrechts MM (2004) Physiological ecology of Mediterranean Blue Tits (Parus caeruleus L). Physiol Bioch Zool 77:492-501

Skwarska J, Kaliński A, Wawrzyniak J, Markowski M, Mikus W, Bańbura M, Glądalski M, Zieliński P, Bańbura J (2012) Longterm variation in laying date and clutch size of Pied Flycatchers Ficedula hypoleuca. Pol J Ecol 60:187-192

Słomczyński R, Kaliński A, Wawrzyniak J, Bańbura M, Skwarska J, Zieliński P, Bańbura J (2006) Effects of experimental reduction in nest micro-parasite and macro-parasite loads on nestling hemoglobin level in blue tits Parus caeruleus. Acta Oecol 30:223-227

Southwood TRE (1984) Insect-plant adaptations. In: Origins and Development of Adaptation: 138-151. Ciba Foundation Symposium 102. London: Pitman

SPSS (2006) SPSS for Windows, Release 15.0 - SPSS Inc

StatSoft Inc (2011) STATISTICA (data analysis software system), version 10. http://www.statsoft.com

Totzke U, Bairlein F (1998) The body mass cycle of the migratory garden warbler (Sylvia borin) is associated with changes of basal plasma metabolite levels. Comp Biochem Physiol A 121:127-133

van Noordwijk AJ, van Balen JH, Scharloo W (1988) Heratibility of body size in natural population of the Great Tit (Parus major) and its relation to age and environmental conditions during growth. Genet Res Camb 51:149-162

Wilson WO (1971) Evaluation of stressor agents in domestic animals. J Anim Sci 32:578-583

Yadava SC (1978) Seasonal changes in the blood contents of Columbia livia (Gmelin). Ann Zool 14:131-148

Zajac T (1995) Selection on laying date in the Blue Tits Parus caeruleus and the Great Tit Parus major caused by weather conditions. Acta Ornithol 30:145-151

Zar JH (1996) Biostatistical analysis Prentice Hall, Upper Saddle River 